\title{
A NATION RISING
}

NARRATING NATIVE HISTORIES

Series Editors

K. Tsianina Lomawaima

Florencia E. Mallon

Alcida Rita Ramos

Joanne Rappaport

Editorial Advisory Board

Denise Y. Arnold

Charles R. Hale

Roberta Hill

Noenoe K. Silva

David Wilkins

Juan de Dios Yapita 


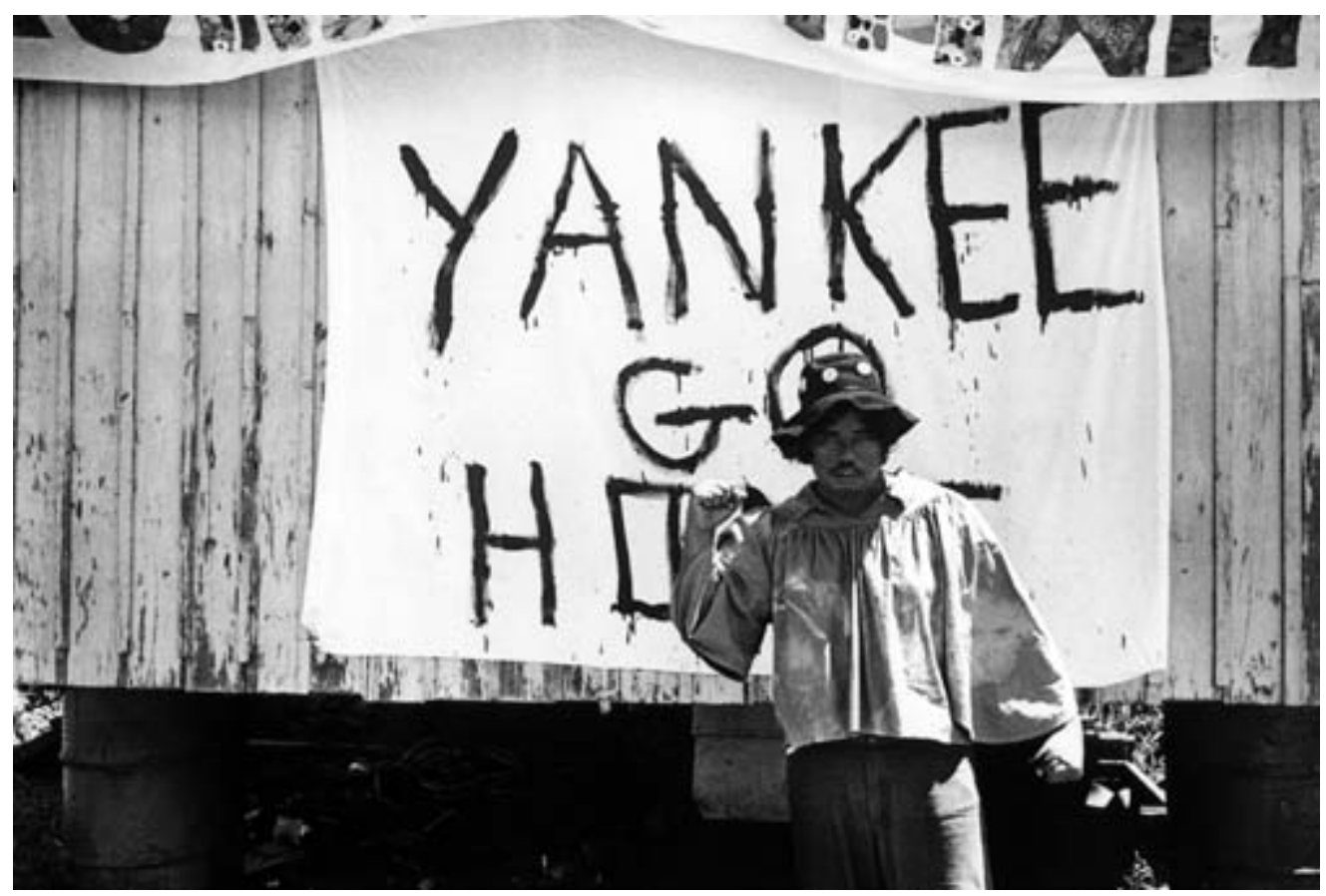



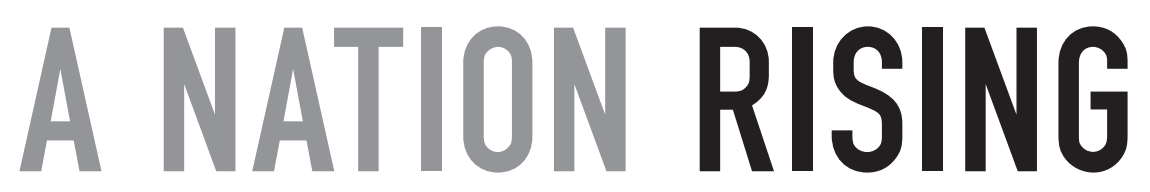

Hawaiian Movements for Life, Land, and Sovereignty

Noelani Goodyear-Ka'ōpua, Ikaika Hussey

\& Erin Kahunawaika'ala Wright, Editors

рнотоgraphs вy Edward W. Greevy

Duke University Press Durham and London 2014 
(C) 2014 Duke University Press

All rights reserved

Printed in the United States of America on acid-free paper $\infty$

Text designed by Chris Crochetière, BW\&A Books, Inc.

Typeset in Arno and Fette Engschrift DIN 1451 by BW\&A Books, Inc.

Library of Congress Cataloging-in-Publication Data

A nation rising : Hawaiian movements for life, land, and sovereignty /

Noelani Goodyear-Ka'ōpua, Ikaika Hussey, and Erin Kahunawaika'ala Wright, editors ; photographs by Edward W. Greevy.

pages $\mathrm{cm}$-(Narrating Native histories)

Includes bibliographical references and index.

ISBN 978-0-8223-5683-7 (cloth : alk. paper)

ISBN 978-0-8223-5695-o (pbk. : alk. paper)

1. Hawaiians-Government relations. 2. Sovereignty. I. Goodyear-Ka'ōpua, Noelani. II. Hussey, Ikaika. III. Wright, Erin Kahunawaika'ala IV. Series:

Narrating Native histories.

DU624.65.N358 2014

$323.1199^{\prime} 42-\mathrm{dc} 23$

2014006868

Duke University Press gratefully acknowledges the support of The Kohala Center, which provided funds toward the publication of this book.

Cover photo: Kumu Hina Wong-Kalu and students of Hālau Lōkahi, 2007.

Frontispiece: “Yankee, Go Home!,” Kalani ‘Ohelo, Kalama Valley, May 1971.

All photographs in the book (c) Edward W. Greevy unless otherwise noted. 
No ka po'e aloha 'āina 
